\title{
Evaluation of Demographic Features of Eyelid Lesions
}

\author{
Korhan Fazil, ${ }^{1}$ () Safak Karslioglu, ${ }^{2}$ () Muslime Akbaba, ${ }^{2}$ () Ibrahim Bulent Buttanri, ${ }^{3}$ () Didem Serin, ${ }^{3}$ \\ Gamze Ozturk Karabulut, ${ }^{1}$ (i) Damla Bektasoglu'
}

1Department of Ophtalmology, University of Health Sciences, Beyoglu Eye Training and Research Hospital, Istanbul, Turkey ${ }^{2}$ Department of Ophthalmology, Istanbul Oculoplastic \& Orbital Surgery and Ocular Oncology Center, Istanbul, Turkey ${ }^{3}$ Department of Ophtalmology, Haydarpasa Numune Training and Research Hospital, $2^{\text {nd }}$ Eye Clinic, Istanbul, Turkey

\begin{abstract}
Objectives: This study was an evaluation of demographic and histopathologic features of eyelid lesions.

Methods: The medical records of $26 \mathrm{I}$ patients (296 eyelid lesions) who attended a single clinic between I 997 and $20 \mathrm{II}$ were examined retrospectively. The incidence of benign and malignant lesions, the pathological classification, and age and sex data were investigated.

Results: A total of 204 benign lesions (68.9\%) and 92 malignant neoplasms (31.1\%) were found. Among these, the most frequently seen types of benign neoplasms were xanthelasma (28.4\%), papilloma (14.7\%), chalazion $(8.8 \%)$, nevus $(6.4 \%)$, moll cyst (5.9\%), and capillary hemangioma (4.9\%). The most frequently seen malignant neoplasms were basal cell carcinoma (72.8\%), squamous cell carcinoma (13\%), and sebaceous gland carcinoma (5.4\%). The study group was made up of I49 (57\%) female patients and $112(43 \%)$ male patients. The majority of benign lesions were seen in women, whereas malignant neoplasms were observed more often in male patients. The mean age of patients with benign lesions and malignant neoplasms was $38.1 \pm 21.7$ and $62.7 \pm 15.3$ years, respectively. Benign lesions involved the upper eyelid more frequently than the lower, while malignant lesions were seen more frequently in the lower eyelid, with the exception of sebaceous gland carcinoma.

Conclusion: The majority of eyelid lesions were benign and malignant neoplasms were seen more frequently in the older population. Basal cell carcinoma was the most common malignant eyelid tumor. The most common site of malignant tumor origin was the lower eyelid, with the exception of sebaceous gland carcinoma.
\end{abstract}

Keywords: Benign, eyelid lesion, malign.

\section{Introduction}

Approximately $5 \%$ to $10 \%$ of all skin tumors are observed in the eyelid and periocular region (I). The most common tumoral lesions seen in the ophthalmology clinic are eyelid tumors $(2,3)$. Eyelids are complex structures consisting of various tissues, including skin, mucosa, and stromal supportive tissue, and they provide a protective function for the eyeball (4). Tumors with different histopathological characteristics can develop from these various structures (2). Patients with a benign lesion usually present at a clinic for cosmetic reasons, although anatomical and functional problems such as ptosis and ectropion can be seen (5). Malignant tumors can cause organ loss by invading the globe, orbit, and brain, and may even lead to life-threatening situations (4). Therefore, it is very important to differentiate the malignant lesions from the benign and treat them according to the diagnosis. However, some benign lesions are known to have the potential risk for malignant transformation. Some lesions that are considered benign according to the clinical features may be reported as malignant after a pathological examination (5-7). In one study, $4.6 \%$ of the eyelid lesions with the clinical diagnosis of benign were reported as malignant histopatholog-

Address for correspondence: Korhan Fazil MD. Beyoglu Goz Egitim ve Arastirma Hastanesi, Saglik Bilimleri Universitesi, Oftalmoloji Bolumu, Istanbul, Turkey

Phone: +90 5323540401 E-mail: korhanfazil@hotmail.com

Submitted Date: May 09, 2020 Accepted Date: May 28, 2020 Available Online Date: June 04, 2020

${ }^{\circ}$ Copyright 2020 by Beyoglu Eye Training and Research Hospital - Available online at www.beyoglueye.com OPEN ACCESS This work is licensed under a Creative Commons Attribution-NonCommercial 4.0 International License. 
ically after excision (8). This emphasizes the importance of histopathological examination.

The objective of this study was to evaluate and present the demographic and histopathological features of patients who presented with a tumoral lesion on the eyelid.

\section{Methods}

The medical records of $26 \mathrm{I}$ cases of eyelid lesions operated on by a single surgeon (ŞK) in 1997-20 I I were evaluated retrospectively in this study. A total of 296 biological material samples were evaluated by the pathology clinic of the same institution. The patients were evaluated in terms of age, sex, affected eyelid, the type of operation, and the histopathological features of the lesions. Patients with incomplete medical records and a lack of reliable clinical data were excluded from the study.

The study protocol was approved by the ethics committee and written informed consent was obtained from all of the patients. The tenets of the Declaration of Helsinki were observed throughout this research.

Statistical analysis was performed using the IBM SPSS Statistics for Windows, Version 26.0 (IBM Corp., Armonk, NY, USA). Pearson's chi-square test and the Mann-Whitney $U$ test were used for the comparison of data between groups. Data with a $p$ value of $<0.05$ were accepted as statistically significant.

\section{Results}

A total of $26 \mathrm{I}$ patients (149 females, II 12 males) with an eyelid lesion were included in the study. The mean age was $46.2 \pm 22.9$ years. In all, I I 7 (44.8\%) of the lesions were seen in the upper eyelid, 109 (4I.8\%) were seen in the lower eyelid, and 35 (13.4\%) were seen in both the upper and lower eyelids. Laterality findings indicated that $42.1 \%$ of the lesions were observed in the right eye and $57.9 \%$ were in the left (Table I).

Table I. Demographic features of the patients

\begin{tabular}{|c|c|c|}
\hline Age $($ Mean $\pm S D)$ (year) & $46.2 \pm 22$ & \\
\hline \multicolumn{3}{|l|}{ Gender (n), \% } \\
\hline Female & 149 & 57 \\
\hline Male & 112 & 43 \\
\hline \multicolumn{3}{|l|}{ Laterality (n), \% } \\
\hline Right & 110 & 42.1 \\
\hline Left & $|5|$ & 57.9 \\
\hline \multicolumn{3}{|l|}{ Eyelid (n), \% } \\
\hline Upper lid & 117 & 44.8 \\
\hline Lower lid & 109 & 41.8 \\
\hline U+ L lid & 35 & 13.4 \\
\hline
\end{tabular}

$\mathrm{n}$ : Number of patients; SD: Standard deviation.
According to the histopathological examination, 204 (68.9\%) lesions were benign and 92 (31. . \%) lesions were malignant. In the group of benign lesions, the most commonly seen types were xanthelasma (28.4\%), papilloma (14.7\%), chalazion (8.8\%), nevus (6.4\%), moll cyst (5\%), and capillary hemangioma (4.9\%). The most common malignant lesions were basal cell carcinoma (BCC) $(72.8 \%)$, squamous cell carcinoma (SCC) (I3\%), and sebaceous gland carcinoma (SGC) (5.4\%).

The mean age of patients with a benign lesion was $38.1 \pm 21.7$ years (range: I-86 years), whereas it was $62.7 \pm 15.3$ years (range: $7-88$ years) for patients with a malignant lesion $(p<0.00 \mathrm{I})$. The majority of the benign lesions were seen in female patients ( $64.6 \%$ women, $35.4 \%$ men), but malignant lesions were more frequently observed in male patients ( $41.9 \%$ women, $58.1 \%$ men) $(p<0.001)$.

Although both benign and malignant lesions were seen more frequently in the left eye, the difference was not statistically significant $(p=0.317)$. Benign lesions $(n=204)$ were observed mostly in the upper eyelid (63.2\%), while the vast majority of malignant lesions $(n=92)$ were observed in the lower eyelid (75\%). Of the lesions observed in the upper eyelid, $84.9 \%$ were benign $(p<0.00 \mathrm{I}$ ) (Table 2 ).

The surgical technique used was a simple excision in |7| patients $(97.7 \%)$ who were clinically diagnosed with a benign lesion, and eyelid reconstruction was performed in 2 patients (I.I\%). Drainage was performed in I case $(0.6 \%)$ with an abscess diagnosis, and in I case with capillary hemangioma diagnosis, an intralesional corticosteroid injection was administered $(0.6 \%)$.

In patients initially diagnosed with a malignant lesion, a simple excision was performed in 43 cases $(50 \%)$, reconstruction after excision in 30 cases $(34.9 \%)$, and exenteration in 13 cases (15.1\%).

\section{Discussion}

The incidence of benign lesions has been found to be higher than that of malignant lesions (82\%-95\%) in the literature $(2,9-1 \mathrm{I})$. In a study conducted by Kandemir et al. (I), the frequency of benign lesions was $69 \%$, while Duman et al. (12) found a ratio of $74 \%$. In contrast to the results of other studies, Coroi et al. (13) reported that benign eyelid tumors (45.8\%) were seen less often than malignant tumors (54.2\%). The most common benign lesions to be reported have been squamous papilloma, nevus, xanthelasma, and seborrheic keratosis with different incidence rates in various studies $(2,6,9-1 I, 14,15)$. In this study, compatible with many studies in the literature, the ratio of benign lesions was found to be $68.9 \%$, and the most common lesion observed was xanthelasma, followed by squamous papilloma, chalazion, and nevus, in descending order. 
Table 2. Demographic characteristics according to benign and malignant lesion groups

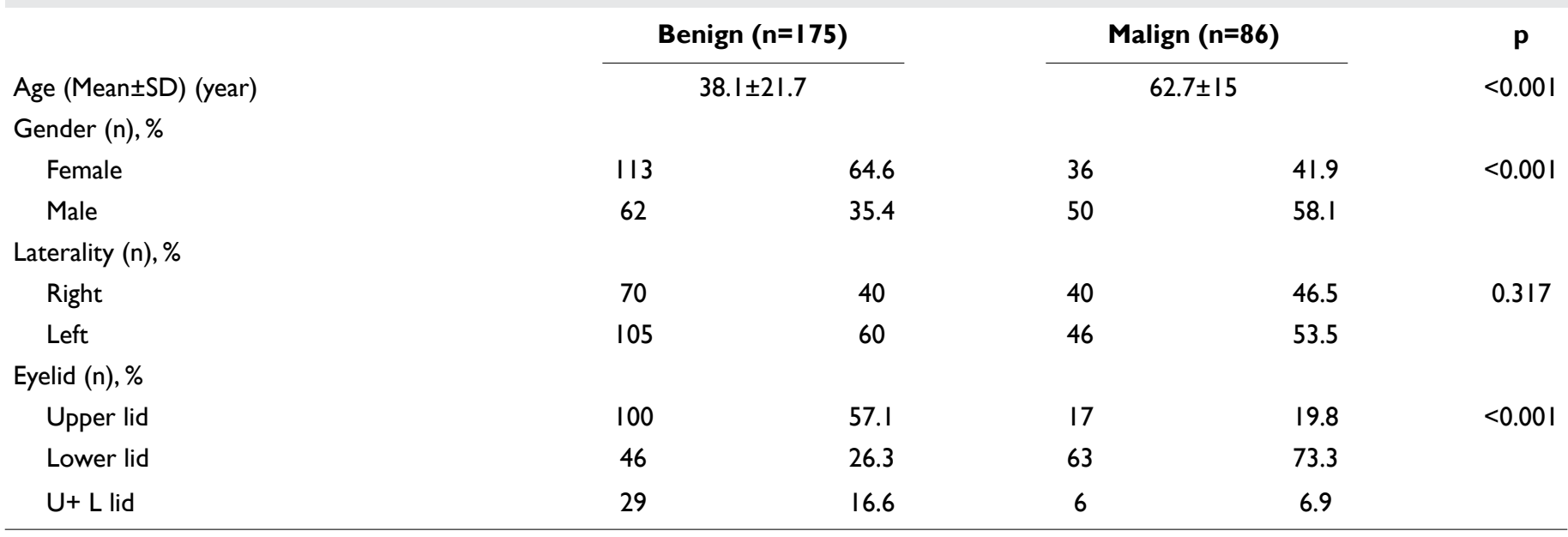

n: Number of patients; SD: Standard deviation.

In several studies, the frequency of malignant lesions ranges from $5 \%$ to $55 \%(2,5,7,9)$. Soysal and Albayrak (4) observed that the most frequent malign eyelid lesion was BCC, followed by SCC, and SGC. In a study conducted by Kaliki et al. (16), the most common malignant lesion was SGC, followed by BCC and SCC. Huang et al. (9) examined $452 \mathrm{I}$ eyelid lesions and also found that the most common malignant lesion was BCC, which is consistent with the current study, but the second most frequently seen malignant tumor was found to be SGC. In another study, performed by Chang et al. (6), the most often observed malignant lesion was BCC, followed by SGC, and SCC. In the current study, the ratio of malignant tumors was determined to be $31.1 \%$ and the most common malignant lesion was BCC (72.8\%), which is consistent with most published studies. SCC (13\%) and SGC $(5.4 \%)$ were observed less frequently.

The mean age of our patients with malignant lesions was significantly higher than that of the patients with benign lesions $(p<0.00 \mathrm{I})$. In a study conducted by Duman et al. (I), the mean age of patients with a malignant lesion was 71.6 years, while it was 49.8 years for those with a benign lesion. Huang et al. (9) found that the mean age of patients with malignant and benign lesions was 72.5 years and 55.4 years, respectively. The mean age of patients with malignant lesions has been reported to be statistically significantly higher than patients with benign lesions in several studies $(3,5,7,10,14)$.

In most of the research, the benign lesions were observed more frequently in the upper eyelid, while most of the malignant lesions were seen in the lower eyelid. An exception among malignant lesions is SGC, which has been observed more frequently in the upper eyelid in the literature $(I, 2,7, I I, I 4, I 5)$. Kaliki et al. (I6) reported that among the malignant lesions studied, only BCC was most seen in the lower eyelid, whereas SCC and SGC were observed more frequently in the upper eyelid. In the current study, 57.1\% of the benign lesions were observed in the upper eyelid and malignant lesions, other than SGC, were predominantly observed in the lower eyelid (73.3\%).

It has also been observed that benign lesions were frequently seen in women, while malignant lesions are seen more often in male patients. Many studies have reported similar results according to gender $(2,9,13)$, but Xiao et al. (10) found that there was no relationship between the histopathological features of the lesions and the gender of the patients. Kurt et al. (5) determined that malignant lesions were more common in women and benign lesions in men.

Although the retrospective nature of this study is a limitation, it is the study with the largest number of cases and the longest follow-up in the native literature.

\section{Conclusion}

The demographic features of a lesion observed at the first patient examination are of great importance in directing the ophthalmologist to the diagnosis. Most eyelid lesions are benign and malignant tumors are more common in the elderly population. A detailed examination using these data will facilitate the recognition of malignant lesions that may be life-threatening and will speed up the procedures required for definitive diagnosis and treatment.

\section{Disclosures}

Ethics Committee Approval: The Ethics Committee of University of Health Sciences Haseki Training and Research Hospital provided the ethics committee approval for this study (13/I I/20192019-40).

Peer-review: Externally peer-reviewed. 
Conflict of Interest: None declared.

Authorship Contributions: Involved in design and conduct of the study (KF, SK, MA); preparation and review of the study (KF, $\mathrm{IBB}, \mathrm{DS}, \mathrm{SK})$; data collection (KF, IBB); and statistical analysis (KF, GOK, DB).

\section{References}

I. Duman R, Yozgat Z, Doğan M, İnan S, Özcan S, Demirciler B, et al. Histopathological Results of the Eyelid Tumors. Acta Oncol Turc 2018;51:13-6. [CrossRef]

2. Deprez M, Uffer S. Clinicopathological features of eyelid skin tumors. A retrospective study of 5504 cases and review of literature. Am J Dermatopathol 2009;31:256-62. [CrossRef]

3. Karabulut HH, Yuyucu Karabulut Y, Şenel E, Dölek Y, Uslu A, Kurşun N. Histopathologic and Demographic Features of Eyelid Tumours. Turk J Dermatol 2014;4:197-20I. [CrossRef]

4. Gökmen Soysal H, Albayrak A. Göz Kapaklarının Primer Malign Tümörleri. T Oft Gaz 2001;31:370-7.

5. Kurt A, Mutlu SN, Yener Hi, Bayram N, Nazlım S. Histopathology Results of Primary Eyelid Tumors. Dicle Med J 20I5;42:72-7. [CrossRef]

6. Chang $\mathrm{CH}$, Chang SM, Lai YH, Huang J, Su MY, Wang HZ, ET AL. Eyelid tumors in southern Taiwan: a 5-year survey from a medical university. Kaohsiung J Med Sci 2003;19:549-54.

7. Çevik SG, Yücel E, Çevik M, Mutlu N. Our Histological Results of the Eyelids and Conjunctiva Tumour. Acta Oncol Turc 2015;48: I 14-7. [CrossRef]

8. Margo CE. Eyelid tumors: Accuracy of clinical diagnosis. Am J
Ophthalmol 1999; 128:635-6. [CrossRef]

9. Huang YY, Liang WY, Tsai CC, Kao SC, Yu WK, Kau HC, et al. Comparison of the Clinical Characteristics and Outcome of Benign and Malignant Eyelid Tumors: An Analysis of 452I Eyelid Tumors in a Tertiary Medical Center. Biomed Res Int 20I5;20I5:45309I. [CrossRef]

10. Xu XL, Li B, Sun XL, Li LQ, Ren RJ, Gao F, ET AL. Eyelid neoplasms in the Beijing Tongren Eye Centre between 1997 and 2006. Ophthalmic Surg Lasers Imaging 2008;39:367-72.

I I. Tesluk GC. Eyelid lesions: incidence and comparison of benign and malignant lesions. Ann Ophthalmol 1985; 17:704-7.

12. Onak Kandemir N, Barut F, Bektaş S, Doğan Gün B, Bahadır B, Yurdakan G, et al. Tumors and Tumor-Like Lesions of the Eyelid and Conjunctiva. Turk Patoloji Derg 2009;25: I I2-7. [CrossRef]

13. Coroi MC, Roşca E, Muţiu G, Coroi T, Bonta M. Eyelid tumors: Histopathological and Clinical Study Performed in County Hos-pital of Oradea between 2000-2007. Rom J Morphol Embryol 2010;5I:I II-5.

14. Çağlar Ç, Güney G, Dönmez O, Baş $Y$, Durmuş $M$. Histopathol-ogy Results of Eyelid Tumors. Turkiye Klinikleri J Ophthalmol 2017;26:25-31. [CrossRef]

15. Göncü T, Çakmak S, Akal A, Oğuz H. Clinicopathological Features of Benign Eyelid Tumors: A Retrospective Analysis of I0I Cases. Turk J Ophthalmol 2014;44:384-7. [CrossRef]

16. Kaliki S, Bothra N, Bejjanki KM, Nayak A, Ramappa G, Mohamed A, et al. Malignant Eyelid Tumors in India: A Study of 536 Asian Indian Patients. Ocul Oncol Pathol 2019;5:210-9. [CrossRef] 